Meta

Journal des traducteurs

Translators' Journal

\title{
The Future of Translator Training
}

\section{Wolfram Wilss}

Volume 37, numéro 3, septembre 1992

URI : https://id.erudit.org/iderudit/004609ar

DOI : https://doi.org/10.7202/004609ar

Aller au sommaire du numéro

Éditeur(s)

Les Presses de l'Université de Montréal

ISSN

0026-0452 (imprimé)

1492-1421 (numérique)

Découvrir la revue

Citer cet article

Wilss, W. (1992). The Future of Translator Training. Meta, 37(3), 391-396.

https://doi.org/10.7202/004609ar

\section{Résumé de l'article}

S'interrogeant sur la formation des traducteurs, tout particulièrement sur les méthodes d'enseignement, les objectifs visés et les méthodes d'évaluation, l'auteur dégage les nombreuses raisons des lacunes et propose diverses solutions pour y remédier en tenant compte des besoins et des orientations du marché de la traduction de l'avenir. 


\title{
THE FUTURE OF TRANSLATOR TRAINING
}

WOLFRAM WILSS

Universität des Saarlandes, Saarbrücken, Allemagne

\begin{abstract}
Résumé
S'interrogeant sur la formation des traducteurs, tout particulièrement sur les méthodes d'enseignement, les objectifs visés et les méthodes d'évaluation, l'auteur dégage les nombreuses raisons des lacunes et propose diverses solutions pour y remédier en tenant compte des besoins et des orientations du marché de la traduction de l'avenir.
\end{abstract}

I wonder if we have reason to be worried about the qualifications of our graduates for the translation profession. Towards the end of my job as the Director of the Saarbrücken School of Translation and Interpretation I am less than ever convinced that our graduates are really well-enough prepared for the tasks waiting for them in their professional activities. I see serious deficits or problems or both in at least three areas:

1. The goals of translator training

2. The methods of translation teaching

3. The assessment of translator performance

Concerning goals I am, of course, referring to the age-old, but none-the-less burning issue of what I would call the "generalist-specialist controversy". Ever since I started my job in Saarbrücken, there has been much discussion as to whether translators (and for that matter interpreters) should be generalists or specialists. This issue has been the subject matter of many articles in our professional journals since at least 1962, but an in-depth research study has to my knowledge never really been undertaken, and what is even more deplorable, an institution such as CIUTI (Conférence internationale des instituts universitaires pour la formation des traducteurs et interprètes) has, as far as I know, never seriously tackled this issue in one of its annual conferences or has made it a permanent topic on the agenda. In essence, there are two facets of looking at the generalist/ specialist controversy: One from the angle of the free-lance translator or translator consortium trying to make a living on the basis of individual contracts in the highly competitive open market, and second from the angle of the in-house translator (working for a specific national or international organisation or an export/import-intensive industrial firm).

It is probably correct to assume that, in discussing this topic, there is a wide variety of opinions. Nevertheless, on the whole, there seems to be a tendency in favour of the generalist approach. i.e., a translator should know, apart from his or her two or three languages, a little bit of many subjects and be able to handle at his or her workstation a large diversity of topics that come his or her way. But in view of the fast growing diversification of even relatively small areas e.g. in the technical field, I am doubtful if this concept of "encyclopedic knowledge" is not a fiction which, in the age of what in German is called Expertentum (dominance of expertise knowledge) may soon turn out detrimental to 
the image of the translation profession, giving it the ring of amateurishness with the inevitable consequence that the translation profession is losing ground, because more and more translation jobs are taken away from the traditionally trained translator and shifted to experts with more or less-developed linguistic knowledge.

Of course, it would be impossible for any translator, no matter how well-trained he or she is, to possess substantial and comprehensive knowledge in all the subject-areas which are potential candidates for practical translational work. What Danica Seleskovitch wrote in 1978 with reference to conference interpreting, namely that "the generalist must understand everything, but to do so he need not possess the knowledge of the specialist" (1978: 62), is, in my view, a problematic formulation. Where does passive knowledge end, and where does active knowledge begin? Danica Seleskovitch goes on to say: "... his (i.e. the interpreter's) level of knowledge need not be identical to that of the speaker, but he must have a comparable level of intellectual ability" (1978: 63). But: Is a comparable level of intellectual ability really enough? The translator is in a more difficult position than the producer of the source text, for two reasons:

1. He must be able to handle two languages, whereas the source language author can concentrate on one language;

2. He must be well-versed in a great diversity of topics, whereas the source text author can be more selective in his knowledge spectre and, in restricting his activities to a more or less well-circumscribed domain-specificity, acquire a level of expertise unobtainable to the translator who is continuously forced to quickly absorb and internalize additional information.

Many persons who have addressed this issue are satisfied with defining the role of the translator as that of a language specialist or communication expert. I am afraid that being a language specialist is simply not enough for expert translation behaviour. A translator who regards himself as a language specialist might just as well give up his job and look for another type of employment. The waning influence of the translator, despite all the brilliant future prospects, and the waning influence of the translation profession, despite all efforts to the contrary, can, at least to some extent, be ascribed to the perpetuated imbalance between language knowledge and expert knowledge in one or several nonlinguistic subject areas. In Saarbrücken, this imbalance is amply documented by the fact that out of a total of approximately 160 semester hours, subdivided in portions of about 20 over a period of eight semesters, no more than 16 are devoted to the study of the nonlinguistic complementary subject, either in the field of technical subjects, economics or international law. To redress this imbalance it would be necessary to redistribute the overall teaching and learning load into portions of about 50 each (50 for language B, 50 for language $\mathrm{C}, 50$ for the nonlinguistic complementary subject and about ten for the native language training), but this would heavily impair the standard in languages B and C.

A few years ago, the outgoing president of the German Association of Interpreters and translators (BDÜ) at the annual conference of the BDÜ in Saarbrücken, predicted a rising demand for qualified translators and interpreters after 1992. This may well be true, but the emphasis is on "qualified," and this seems to me, as indicated, the crux of the matter. Do we impart on our students the right type of qualifications, and if not, what can and must we do to improve the situation?

How critical the present state of affairs is, becomes evident by the fact - to quote just one example - that the Bundessprachenamt (Federal Language office in Hürth near Bonn) has organized a two-year in-house programme for the additional training of university graduates. In other words: after at least four years of intensive training at the 
German CIUTI institutes our graduates, in the eyes of the Federal Language Office, are simply not qualified enough to be entrusted a job as a qualified technical translator. The deficit is obviously less in the area of linguistic knowledge than in the realm of nonlinguistic knowledge.

There is therefore reason to speculate on whether it would make more sense or be a more efficient undertaking to train subject-matter experts as translators in tightly packed one-year linguistic courses focussing entirely on translation from language $\mathrm{B}$ - or languages $\mathrm{B}$ and $\mathrm{C}$ - into native tongue. On the other hand, one might also wonder if it would be not more realistic to expect those who are already linguistically well-trained to acquire - again in tightly packed courses and perhaps in cooperation with prospective employers - to broaden and deepen the knowledge in specific areas such as economics or engineering or linguistic data processing.

If I am not mistaken - if I am, please correct me afterwards - the fact cannot be denied that the translator with specialized knowledge and experience is almost universally in high demand, and I would venture the prediction that this type of translator will become even more prevalent after 1992. If this perspective is realistic, it would, of course, or should, of course, have an immediate impact on the traditional generalist approach in translator training. In the Federal Republic of Germany, only Hildesheim, which is not (yet) a CIUTI member, seems to have been able to read the writing on the wall: They are offering a programme "Fachübersetzen" (expert translation) and, in doing this, in my view are on the right track.

I have some information through reading an article by Ben Teague from the USA which appeared in 1982, that the ATA (American Translators Association) is discussing or has been discussing a project leading to special certification in scientific and technical translation and to work out tests to find out about the subject expertise among its members. In 1983, Teague and one of his colleagues (David Sharpe) presented a list of no less than 92 subjects (based on the Library of Congress Classification) for specialized certification examinations. At the 1984 ATA Annual Meeting in New York, which I was able to attend, this programme, which has become known under the name of ATACERT, was discussed by Henry Fischbach, and he mentioned the need to implement the proposed certification procedure immediately. I do not know whether this procedure has been put into practice, but our colleagues, the two Bowens and Professor Weber, presumably know more about it than I do.

Another factor which in my view has so far not sufficiently been taken care of by CIUTI, is, as I mentioned in my lecture last year, speed of translator performance. Speed is, in my view, an important criterion for efficient translation behaviour. Since translation is dictated by the communicative needs and requests of the prospective client, the concept that "fast is smart" permeates the whole translation world. Every person that makes a living by translation knows that rapid performance, rapid learning, rapid parallel-text research and rapid decision-making are properties that are absolutely imperative if one tries to keep one's head above water and to efficiently cope with a translation job under the prescribed situational conditions. Among these conditions speedy delivery of a translation product of an acceptable qualitative standard is definitely the main factor for successful translational performance. It is rare, if not impossible, to be involved in a translation situation that does not force the translator to work under time pressure, often exceeding his mental resources, thereby conjuring up the necessity of putting up with a piece of work that would have been of better quality had the translator been allowed the appropriate amount of time. I am not going to dwell on this aspect of translation performance, because I have said more about it in an article which was published in TARGET $1: 2,1989$, pp. 129-149. Combining speed and quality is, of course, a particularly thorny 
issue for translation pedagogy for which I can offer no practical solution, but perhaps we, as a body of people with a lot of Sachverstand (expert knowledge) can, if we make a concerted effort and start thinking about the implication of the to-be-expected developments in the translation profession.

Concerning the issue of translation teaching, I must start with a disillusioning statement. I do not know how you feel about it, but in my view translation teaching is in a rather chaotic stage - everybody obviously developing his or her own didactic strategies often without much consideration for an acceptable input/output-relation. I trust you will agree that, like any act of linguistic communication, translation is a mental activity, in which internalized, "elementary" transfer procedures, such as literal translation, and more intricate transfer procedures, such as nonliteral translation, occur side by side and that both types of translational behaviour are amenable to didactic manipulation. Now, what the performance of university-trained translators, virtually incontrovertibly, should show is that whatever differences in translational abilities may in the early training stage be noticeable, consistent, pedagogically well-reflected translation training, perhaps starting from the two dichotomies literal/nonliteral and obligatory/optional, must play the decisive role in determining the graduate's ultimate level of translational performance. If the translator-trainee is himself motivated to achieve a high performance level, and if proper means of monitoring and crystallizing the translational learning process are made available, a translator-trainee can attain a remarkable competence level. Of course, not all translational problems are solved in the same way. There remains the notion of taskspecificity where every task requires its own capacities and problem-solving strategies. There are literary texts which may predominantly require a hermeneutic approach; on the other hand, there may be LSP texts which require a predominantly analytic approach, and there is for the most part only a weak interrelation in handling these two areas from a translator's point of view. Depending on the kind of information-processing device which one has available, and the analysis of the intellectual abilities which one embraces, there will be a very different picture of what the translational information processor is like and which type of intelligence secures adequate translational performance.

All of these insights - and, of course, many more - seem to be well worth integrating into a comprehensive account of translational teaching and learning, thereby keeping in mind - and AI research is a good illustrative example - that information processing is as yet more of a tentative approach than a full-fledged concept. What is missing from this approach - and this is particularly true of the teaching of translational information-processing - is a recognition of the fact that individual translators may differ appreciably from one another in intellectual strength, in the ability (and willingness) to learn, in the text-type-specific use of their mental faculties, be it in a more novelty-oriented, attentive, or a more routine-oriented, automatized manner. From a didactic point of view, it is important to deal with this variation in translation performance. We all know that individual translators may make only modest progress in their field, despite massive assistance from the surrounding pedagogical milieu, whereas others move forward, without much help from outside, to truly remarkable accomplishments in mastering the wide and various fields of translation procedures.

If we start exploring the general framework in which translation learning takes place, we find that this issue may be two-faceted. There is first the strategy of acquiring translational performance through formal channels. In a complementary fashion, translation learning can also take place in another setting, which may be called "unmediated" or "observational" learning. Today, I am, of course, only discussing the first facet, because we are all representatives of formalized translation teaching. Thus, a translator-trainee or 
rather a group of translator-trainees may learn how to translate through the demonstration of translation procedures in a course aiming at translational skills or through active participation in a translation project that is guided by an experienced and well-prepared translation teacher.

This type of translational teaching takes place outside the context in which translation skills are customarily practiced. Since translation has become rather complex and translation tasks are more intricate and multifactorial than previously, much translation learning today takes place in university schools with which the majority of people employed in the translation profession nowadays have an intimate familiarity. There have been many complaints recently (at least in West Germany) that this type of instruction is too far removed from the actual site of practice and that therefore a closer cooperation between translation teaching on the one side and translational practitioners on the other is imperative in an attempt to combine the systematic features of formal translation teaching with the practical advantages of collecting translational experience by on-the-job training, on the basis of translator-trainee-tailored apprenticeships of one sort or another.

One asset of institutionalized translation teaching and translation learning may be that, at least ideally, a group of students may in the course of time acquire a comparable set of knowledge and skills, but how to efficiently mediate this knowledge and these skills seems to be a problem that has so far received only little systematic scrutiny. There is a consensus only in so far that all CIUTI institutes seem to recognize the fact that textual knowledge is at a premium and that a large amount of sociocultural knowledge is also of great value. Here translation teaching should forge an integrated middle position, a position that takes seriously the nature of innate predisposition, the partly heterogeneous, partly homogeneous development of the mental faculties of the oncoming translator, the influence of the sociocultural values of various societies, and the relevance of text-specific and text-type-specific research keeping in mind the fact that texts can be similar in their structural properties, but very episodic in terms of content and stylistic presentation.

Concerning the assessment of translator performance, I will in conclusion make only one or two scattered statements. For every translation goal being pursued, there should be appropriate ways and means for testing the behaviour of would-be translators and to see how rapidly (or slowly) they are making progress in a limited period of time. This situation places a strong demand on the tester to locate problems that are hampering the student in his development and to design strategies that are catalytic for the improvement of translation behaviour in particular domains.

It should be possible to gain a reasonably accurate basis for the assessment of a translator-student's intellectual profile over a period of four to five years, provided the teacher is confronted with only a sharply limited number of students in regular classroom activities. Given a wide range of translational goals and an even greater variety of translator profiles, the task of obtaining a match between flexible student performance and flexible teaching methodology practiced in translator training is simply overwhelming and puts a huge burden on the overall educational planning process. A principal decision must be made about which evaluative regimen to follow. Normally such decisions are made on an intuitive basis establishing an experimental taxonomy of potential translational difficulties and of the general linguistic, extralinguistic and sociocultural impact a particular text makes on the student.

Research in the field of translation teaching (as a systematic subdiscipline of translation studies) and in the field of objectified translation assessment is still fairly young. It is doubtless desirable to move away from global concepts such as a general translation 
competence. What is necessary is to consider the manifold issues of translation performance and to keep in perspective the need for orchestration of curricula not only across various learner groups, but possibly also across CIUTI institutes. An important point in this connection is to avoid redundancy or gaps in curricula and to develop criteria about the array of intellectual powers on which a student-trainee can draw. The result of these deliberations could be an ensemble of didactic strategies that ensure rapid mastering of what needs to be mastered and thus open the way for the student to proceed along optimal paths of developing translational expertise both in the field of creative and routine translational skills. 